\title{
Effect of Ascorbic Acid, 8-Hydroxyquinoline Sulfate and Sucrose on the Longevity and Anthocyanin Content of Cut Gerbera Flowers
}

\author{
SAMANEH BANAEE ${ }^{1}$, EBRAHIM HADAVI' and PEJMAN MORADI² \\ ${ }^{1}$ Department of Horticulture, Karaj branch, Islamic Azad University, Karaj, Iran. \\ ${ }^{2}$ Department of Horticulture, Saveh branch, Islamic Azad University, Saveh, Iran.
}

(Received: April 03, 2013; Accepted: June17, 2013)

\begin{abstract}
The effects of ascorbic acid (AsA), 8-hydroxyquinoline sulfate (8-HQS) and sucrose (Suc) on cut gerbera was studied. AsA (0,100 and $\left.150 \mathrm{mg} \mathrm{L}^{-1}\right), 8-\mathrm{HQS}\left(0\right.$ and $\left.200 \mathrm{mg} \mathrm{L}^{-1}\right)$ and Suc $\left(0\right.$ and $\left.30 \mathrm{~g} \mathrm{~L}^{-1}\right)$ and their combinations were tested as preservative mixtures. Vase life was determined as the days until the flowers started to wilt and then dry weight and anthocyanin content were measured. The following records were analyzed at the $7^{\text {th }}$ day of experiment: mean uptake of preservative solution, dry weight, flower diameter and quality score of cut flowers. The only measure improved by ascorbic acid was the flower diameter. The 8-HQS treatment increased vase life, dry weight, anthocyanin content, fresh weight, flower diameter and mean uptake of preservative solution. Sucrose decreased vase life, anthocyanin content and increased dry weight and flower diameter and mean uptake of preservative solution. The treatment containing the combination of $100 \mathrm{mg} \mathrm{L}^{-1} \mathrm{AsA}+200 \mathrm{mg} \mathrm{L}^{-1} 8-\mathrm{HQS}+30 \mathrm{~g} \mathrm{~L}^{-1}$ sucrose resulted in the highest vase life but this was not significantly different from the controls. The highest anthocyanin content was noted in the $150 \mathrm{mg} \mathrm{L}^{-1} \mathrm{AsA}$ treatment. The combination of $100 \mathrm{mg} \mathrm{L}^{-1} \mathrm{AsA}+200 \mathrm{mg} \mathrm{L}^{-1} 8-\mathrm{HQS}+$ $30 \mathrm{~g} \mathrm{~L}^{-1}$ Suc resulted the highest flower diameter. We conclude that AsA could improve the anthocyanin content and flower diameter of flowers and its addition to preservative mixtures based on 8-HQS could improve its effect to a limited extent.
\end{abstract}

Key words: 8-HQS, dry weight, fresh weight, preservative solution, vase life

Abbreviations: AsA, Ascorbic acid; Suc, Sucrose; 8-HQS, 8-hydroxyquinoline sulfate.

\section{INTRODUCTION}

Gerbera is a genus of ornamental plants from the Asteraceae family. It has roughly 30 species in the wild, extending to South America, Africa and tropical Asia ${ }^{1-2}$. The inflorescences of Gerbera hybrida (Asteraceae) are composed of three different types of flowers (ray, trans, disc) that are tightly packed into a condensed, radially organized capitulum ${ }^{3}$. Most of the present commercially cultivated varieties originate from the artificial crossing progenies of $G$. jamesonii and $G$. viridifolia, both South African species since natural hybrids of the two species have not been found ${ }^{2}$.
Gerbera is one of the most important commercially grown flower crops in the world. Gerbera is popular owing to its bright and vivid petal color, which is available in different shades and hues and a large flower size. It has multiple uses in flower arrangements and bouquets and dry flower crafts $^{4-5}$.

However, they often suffer from short vase life $^{6}$. Addition of chemical preservatives to the holding solution is recommended to prolong the vase-life of cut flowers. All holding solutions usually contain two ingredients namely, sugar and germicides. The sugars provide a respiratory substrate, while the germicides control bacterial 
growth and prevent plugging of the conducting tissues. Therefore, the techniques of prolonging the vase-life of flowers will be a great asset to the growers and users ${ }^{4}$. Different preservative mixtures are used for vaselife prolongation of gerbera including nano silver ${ }^{6}$ and silver nitrate+sucrose ${ }^{4}$. Sucrose and ascorbic acid combinations induced extended vase life in Red ginger (Alpinia purpurata) $)^{7}$. Ascorbic acid at $150 \mathrm{mg} \mathrm{l}^{-1}$ significantly increased the vase life, fresh weight and percentage of total carbohydrates and increased cut snapdragon flowers vase life $^{8}$. Similar reports with $4 \mathrm{mM}$ AsA on rose exists 9 .

In this study, we aimed to find out the interaction effect between different concentrations of AsA, 8-HQS and Suc on vase life of gerbera cut flowers.

\section{MATERIALS AND METHODS}

\section{Plant material and storage conditions}

Cut gerbera flowers were obtained from a local commercial greenhouse (Pakdasht, Tehran, Iran), and transported with proper covers immediately to Laboratory (horticulture laboratory of agriculture faculty of Islamic Azad university, Karaj Branch).

Solutions were freshly prepared at the start of experiments. Stems were recut to $45 \mathrm{~cm}$ length. In this study three levels of ascorbic acid (AsA) (0, 100 and $\left.150 \mathrm{mg} \mathrm{l}^{-1}\right)$, two levels of Suc ( 0 and $3 \% \mathrm{w} /$ v) and two levels of 8 -HQS $\left(0,200 \mathrm{mg} \mathrm{I}^{-1}\right)$ were applied. After recording the fresh weight, each flower was placed in a bottle containing $400 \mathrm{ml}$ preservative solutions. The flowers were held at ambient temperature (22 \pm 2 !). Vase life, anthocyanin content of petal, fresh weight, flower diameter and uptake of preservative mixture were recorded.

\section{Vase life}

Vase life was determined as the number of days to wilting of flowers. The flowers were checked once a day for signs of deterioration.

\section{Determination of anthocyanin content of petal}

Anthocyanin was extracted and measured based the method described by Ervin et al., ${ }^{10} .0 .5 \mathrm{~g}$ petal tissue was extracted with acidified methanol $(1 \% \mathrm{HCl}, \mathrm{w} / \mathrm{v})$ for $48 \mathrm{~h}$ at room temperature in darkness. The absorbance was measured with spectrophotometer at $530 \mathrm{~nm}$ (peak absorption of anthocyanin) and $657 \mathrm{~nm}$ (peak absorption of chlorophyll degradation products). The formula $A^{530}$ $-\left(0.25 \times A^{657}\right)$ was used to calculate the anthocyanin content.

\section{Fresh weight and dry weight}

All Flowers were weighted at the beginning and at the $7^{\text {th }}$ day of experiment. The flowers were dried in oven and the dry weight was calculated.

\section{Mean uptake of preservative solution per flower in course of experiment}

The solution uptake was calculated by subtracting the mean volume of water evaporated from three-control bottles without cut-flowers, from the water decreased in bottles containing flowers during experimental course.

\section{Experimental design and statistical analysis}

The study was arranged in a factorial test with complete randomized design with three replications. Each replication consisted of three cut flowers. Analysis of variance was performed on the data collected using the general linear model (GLM) procedure of the SPSS software (Version 16, IBM Inc.). The mean separation was conducted by Duncan analysis in the same software $(p=0.05)$. For the data which were gathered once a day until day 7 of experiment (fresh weight, flower diameter and stem diameter), the GLM-repeated-measures module was applied for factorial analysis and related statistics is presented.

\section{RESULTS AND DISCUSSION}

Flower diameter was the only measure that was improved by AsA. Sucrose alone decreased vase life and anthocyanin content and increased dry weight. The flower diameter and mean uptake of preservative solution were affected positively by Suc, conditioned that 8 -HQS was present (Table 1).

The 8-HQS factor significantly increased the vase life, dry weight, anthocyanin content, fresh 


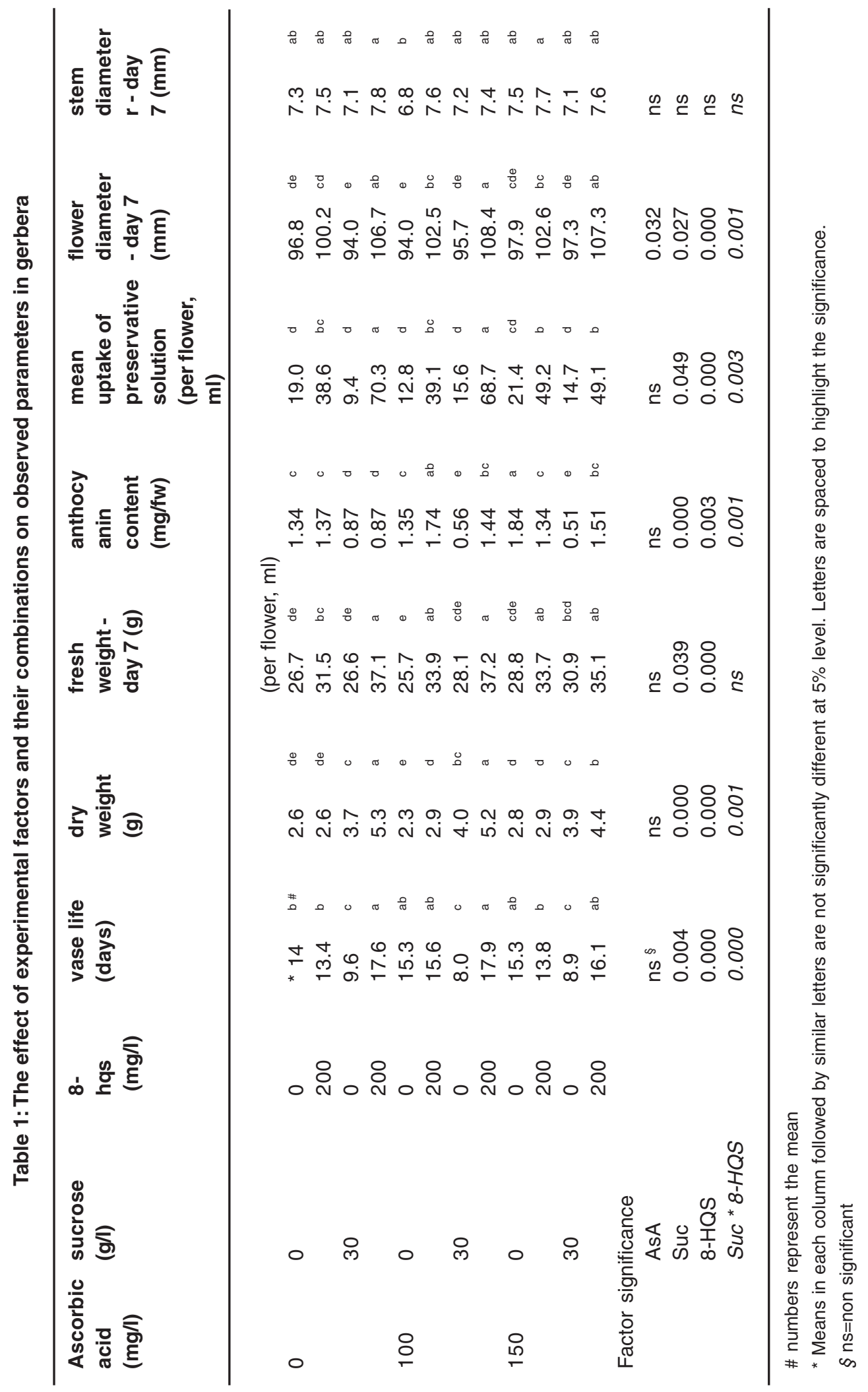


weight, flower diameter and mean uptake of preservative solution. A synergistic effect on dry weight was obvious by interaction of 8-HQS and Suc. The highest dry weight was noted in treatments containing both $30 \mathrm{~g} \mathrm{~L}^{-1}$ Suc and $200 \mathrm{mg} \mathrm{L}^{-1} 8-\mathrm{HQS}$ (table 1). The direct effect of 8-HQS on dry weight is significant; being noticeable when AsA is present. When considering the fresh weight the situation is different. The interaction between 8-HQS and Suc is missing while presence of 8 -HQS is the determining factor affecting on fresh weight. This phenomena points out the determining effect of 8HQS on water absorption, as a similar pattern could be observed in effect of 8-HQS on mean uptake of preservative solution. The germistatic effect of 8HQS that is described elsewhere ${ }^{11-14}$, and is readily highlighted in our experiment as higher mean uptake of preservative solution values (table 1), where the combinations of 8-HQS and Suc show highest mean uptake of preservative solution values but when Suc is applied alone caused a steep decrease in mean uptake of preservative solution value. This reflects the inhibitory effect of 8-HQS on bacterial colonization and clogging of xylem vessels in cut surface of the flower stem as reported earlier ${ }^{15-}$ ${ }^{16}$. The flower diameter followed a similar pattern to mean uptake of preservative solution; being in maximum when both Suc and 8-HQS were present, regardless of AsA concentration.
A synergism between 8-HQS and AsA opposed the decreasing effect of pure Suc on anthocyanin content. The highest anthocyanin content was noted in the treatment containing just $150 \mathrm{mg} \mathrm{L}^{-1}$ AsA.

Contrary to the result obtained on red ginger, snapdragon and rose cut flowers, any increasing effect by AsA on vase life was not noticed ${ }^{7-}$ 9. The treatment containing the combination of 100 $\mathrm{mg} \mathrm{L}^{-1} \mathrm{AsA}+200 \mathrm{mg} \mathrm{L}^{-1} 8-\mathrm{HQS}+30 \mathrm{~g} \mathrm{~L}^{-1}$ sucrose resulted in the significantly longest vase life, largest flower diameter, more dry and fresh weight and the highest mean uptake of preservative solution. The similar treatment without AsA had similar effect on all mentioned parameters but in addition, it had significantly lower anthocyanin content. A significant correlation between mean uptake of preservative solution and vase life and flower diameter was noticed as reported earlier ${ }^{17}$ (Table 2).

We conclude that AsA could improve the anthocyanin content and flower diameter of flowers and adding it to preservative mixtures based on 8HQS could improve its effect in a limited extent. Based on the increasing effect of 8-HQS on dry weight it seems that it may have supplied the cut flower as a carbon source as well as having germistatic effect in preservative mixture.

Table 2: Cross correlation table

\begin{tabular}{|c|c|c|c|c|c|c|}
\hline & $\begin{array}{l}\text { Vase Life } \\
\text { (days) }\end{array}$ & $\begin{array}{l}\text { Dry } \\
\text { weight } \\
\text { (g) }\end{array}$ & $\begin{array}{l}\text { Anthocyanin } \\
\text { content } \\
\text { (A530/657; } \\
\text { mg FW) }\end{array}$ & $\begin{array}{l}\text { Fresh } \\
\text { weight - } \\
\text { day } 7 \\
\text { (g) }\end{array}$ & $\begin{array}{l}\text { Flower } \\
\text { diameter } \\
\text { - day } 7 \\
(\mathrm{~mm})\end{array}$ & $\begin{array}{l}\text { Stem } \\
\text { diameter } \\
\text { - day } 7 \\
(\mathrm{~mm})\end{array}$ \\
\hline dry weight (g) & 0.100 & & & & & \\
\hline \multicolumn{7}{|l|}{ Anthocyanin content } \\
\hline (A530/657; mg FW) & $0.632 * *$ & $-0.397 *$ & & & & \\
\hline fresh weight -day 7 (g) & 0.396 * & $0.627^{\star \star}$ & 0.086 & & & \\
\hline flower diameter - day 7 (mm) & $0.578^{* *}$ & $0.590 * *$ & 0.287 & $0.849^{* *}$ & & \\
\hline stem diameter - day $7(\mathrm{~mm})$ & 0.240 & 0.248 & 0.138 & $0.594^{* *}$ & $0.563^{* *}$ & \\
\hline $\begin{array}{l}\text { Mean uptake of preservative } \\
\text { solution; } \mathrm{ml}\end{array}$ & $0.627^{* *}$ & $0.529 * *$ & 0.207 & $0.779 * *$ & 0.786 ** & $0.355 *$ \\
\hline
\end{tabular}

**. Correlation is significant at the 0.01 level (2-tailed).

*. Correlation is significant at the 0.05 level (2-tailed). 


\section{REFERENCES}

1. Bremer K. Asteraceae: cladistics and classification: Timber Press: Portland, Oregon; 1994.

2. Hansen HV. A taxonomic revision of the genus Perdicium (Compositae Mutisieae). Nordic journal of botany 5(6): 543-6 (1985).

3. Kotilainen M, Elomaa P, Uimari A, Albert VA, Yu D, Teeri TH. GRCD1, an AGL2-like MADS box gene, participates in the $C$ function during stamen development in Gerbera hybrida. The Plant Cell Online 12(10): 1893 (2000).

4. Nair SA, Singh V, Sharma T. Effect of chemical preservatives on enhancing vase-life of gerbera flowers. Journal of Tropical Agriculture 41: 56-8 (2003).

5. Patel T, Singh A, editors. Effect of Different Modified Atmosphere Packaging (MAP) Films and Cold Storage Temperatures (5, 10 and $15 \mathrm{C}$ ) on Keeping Quality of Gerbera (Gerbera jamesonii) Flowers (2008).

6. Liu J, He S, Zhang Z, Cao J, Lv P, Cheng G, Joyce DC. Nano-silver pulse treatments inhibit stem-end bacteria on cut gerbera cv. Ruikou flowers. Postharvest Biology and Technology 54(1): 59-62 (2009).

7. Islam M, Mehraj $\mathrm{H}$, Roni M, Mahasen $\mathrm{M}$, Uddin AJ. Influence of sucrose and ascorbic acid on vase life of red ginger (Alpinia purpurata Vieill.). Bangladesh research publications journal 8(1): 104-6 (2013).

8. Abdulrahman YA, Ali SF, Faizi HS. Effect of Sucrose and Ascorbic Acid Concentrations on Vase Life of Snapdragon (Antirrhinum Majus L.) Cut Flowers. Int J Pure Appl Sci Technol 13(2): 32-41 (2012).

9. Abri F, Ghasemnezhad M, Hasansajedi R, Bakhshi D. Effect of Ascorbic Acid on Vase Life and Petal Senescence in Cut Rose Flowers (Rosa hybrida) cv.'Royal Class'. enzyme 2: 2 (2013).
10. Ervin EH, Zhang X, Fike JH. Ultraviolet-B radiation damage on Kentucky Bluegrass II: Hormone supplement effects. HortScience 39(6): 1471-4 (2004).

11. Ichimura K, Kojima K, Goto R. Effects of temperature, 8-hydroxyquinoline sulphate and sucrose on the vase life of cut rose flowers. Postharvest Biology and Technology 15(1): 33-40 (1999).

12. Srilaong V, Buanong $M$, editors. Effect of Hydroquinone Pulsing Treatment on Vase Life of Cut Rose. International Conference on Quality Management in Supply Chains of Ornamentals 755 (2007).

13. Jianbo H. Study on the Fresh-keeping Effect of 8-HQS and CA with Different Concentrations on Cut Flowers of Carnation"Matute". Journal of Anhui Agricultural Sciences 36(3): 965 (2008).

14. Locke EL. Extending cut flower vase life by optimizing carbohydrate status: preharvest conditions and preservative solution. Raleigh,: North Carolina State University; (2010).

15. Abdel-Kader $\mathrm{H}$, Rogers $\mathrm{MN}$, editors. Postharvest treatment of Gerbera jamesonii. III International Symposium on Postharvest Physiology of Ornamentals 181 (1985).

16. Prashanth P, Sekhar R, Reddy K. Influence of floral preservatives on scape bending, biochemical changes and post harvest vase life of cut gerbera (Gerbera jamesonii bolus ex. Hook.). Asian Journal of Horticulture 5(1): 1-6 (2010).

17. Jamshidi M, Hadavi E, Naderi R. Effects of Salicylic Acid and Malic Acid on vase life and bacterial and yeast populations of preservative solution in cut Gerbera flowers. International Journal of AgriScience 2(8): 671-4 (2012). 